\title{
Natural Killer Activity in Preleukemic States
}

P. Obłąkowski ${ }^{1}$

\section{A. Introduction}

Natural killer cells (NKC) were first identified by their ability to kill without prior immunization certain tumor target cells grown in vitro $[15,16,20]$. In preliminary observations they were defined only in negative terms: that is, they were not thymus-derived (T) or bone marrow-derived (B)-lymphocytes, nor were they adherent or phagocytes, and they lacked demonstrable surface membrane immunoglobulin [17]. Most human blood NKC bear an Fcy receptor [23]. As with rodents, a number of observations suggested that NKC were not necessarily divorced from the T-cell lineage. For example, they reacted with anti-T serums and anti-T monoclonal antibodies $[5,9,11]$. On the basis of the partial isolation of $\mathrm{NKC}$ on Percoll, they were characterized as identical to large granular lymphocytes (LGL) with cytoplasmic azurophilic granules [1, 21]. NKC and their regulation by interferons (IFN) and interleukin-2 (IL-2) are proposed to be one of the important factors in tumor immunosurveillance and tumor resistance $[3,4,8,14,18,22]$. A significant reduction in NKC activity has been demonstrated in patients with various disorders such as the Chédiak-Higashi syndrome which are known for their high incidence of malignant diseases $[6,13]$. It was of interest to examine $\mathrm{NKC}$ activity in preleukemic states and to determine its influence on the development of the disease.

\footnotetext{
${ }^{1}$ Department of Internal Medicine, Institute of Hematology, 00-957 Warsaw, Poland
}

\section{B. Patients and Controls}

Natural killer (NK) activity was determined in 20 patients ranging in age from 30 to 79 years (mean 59.9). There were six cases of acquired idiopathic sideroblastic anemia (AISA), nine cases of refractory anemia (RA), four cases of refractory anemia with an excess of blasts (RAEB), and one case of refractory anemia with an excess of blasts in transformation (RAEBt). The patients were

Table 1. Diagnosis in 20 patients examined

\begin{tabular}{lll}
\hline & \multicolumn{2}{l}{ No. of patients } \\
\cline { 2 - 3 } & Female & Male \\
\hline $\begin{array}{l}\text { Acquired idiopathic } \\
\text { sideroblastic anemia } \\
(\text { AISA) }\end{array}$ & 5 & 1 \\
$\begin{array}{l}\text { Refractory anemia (RA) } \\
\text { Refractory anemia with } \\
\begin{array}{l}\text { an excess of blasts } \\
\text { (RAEB) }\end{array}\end{array}$ & 3 & 2 \\
RAEB in transformation & 0 & 1 \\
\hline
\end{tabular}

classified as AISA, RA, RAEB, and RAEBt according to the FAB classification of myelodysplastic (preleukemic) syndromes [2] (Table 1). All patients had less than $10 \%$ of blasts in peripheral blood, and none received drugs which might influence NK cell activity. A control group constituted of 56 healthy blood donors. 


\section{Effector Cells}

Effector cells were obtained by sedimentation of heparinized blood on "Lymphoprep". Mononuclear cells were washed and resuspended in MEM supplemented with $10 \%$ FCS.

\section{Target Cells}

Cells of the K 562 line derived from a patient with blast crisis in CML were used as targets [7]. K562 cells were cultured in RPMI 1640 medium containing $10 \%$ FCS, gentamicin and L-glutamine, under standard conditions.

\section{E. Cytotoxicity Assay}

NK activity of mononuclear cells was measured in a 4-h cytotoxicity test with ${ }^{51} \mathrm{Cr}-\mathrm{la}$ beled K562 cells as targets [16]. After 4-h incubation of effector cells together with targets in a 20:1 ratio, cells were centrifuged and supernatants were collected for determination of released ${ }^{51} \mathrm{Cr}$ in a gamma scintillation counter.

The percentage of cytolysis was calculated according to the formula:
Maximal cpm was obtained by the incubation of target cells in the presence of $1 \%$ Triton X-100; spontaneous cpm was obtained by the incubation of target cells in MEM containing $10 \%$ FCS.

The results revealed strong suppression of NK activity in all of the preleukemic patients $(11.5 \% \pm 10.1 \%)$ and in each of the diagnosed syndromes, as compared with the control group $(30.6 \% \pm 11.5 \%$; Table 2 and Fig. 1). The difference was statistically significant $(P<0.01)$ in the Wilcoxon-MannWhitney test. Similar changes in NK activity in preleukemia have been detected by others $[12,19]$. There are reports that suppression of NK activity was not connected with dilution of effector cells by blasts or by a reduced frequency of LGL in mononuclear cells of examined patients. Takagi and co-workers suggested that suppression of NK activity in preleukemic patients was caused by the impaired IFN-linked regulatory system of NKC [19].

In this study, two of the 20 investigated patients developed leukemia 2-3 months after diagnosis. Both cases showed very low NK activity:

1. Patient M.S. (RAEB) $\%$ CTX $=-4.2 \%$

2. Patient W.M. (RAEBt) \%CTX = $-1.7 \%$

$\% \mathrm{CTX}=\frac{\text { experimental } \mathrm{cpm}-\text { spontaneous } \mathrm{cpm}}{\text { maximal } \mathrm{cpm}-\text { spontaneous } \mathrm{cpm}} \times 100$

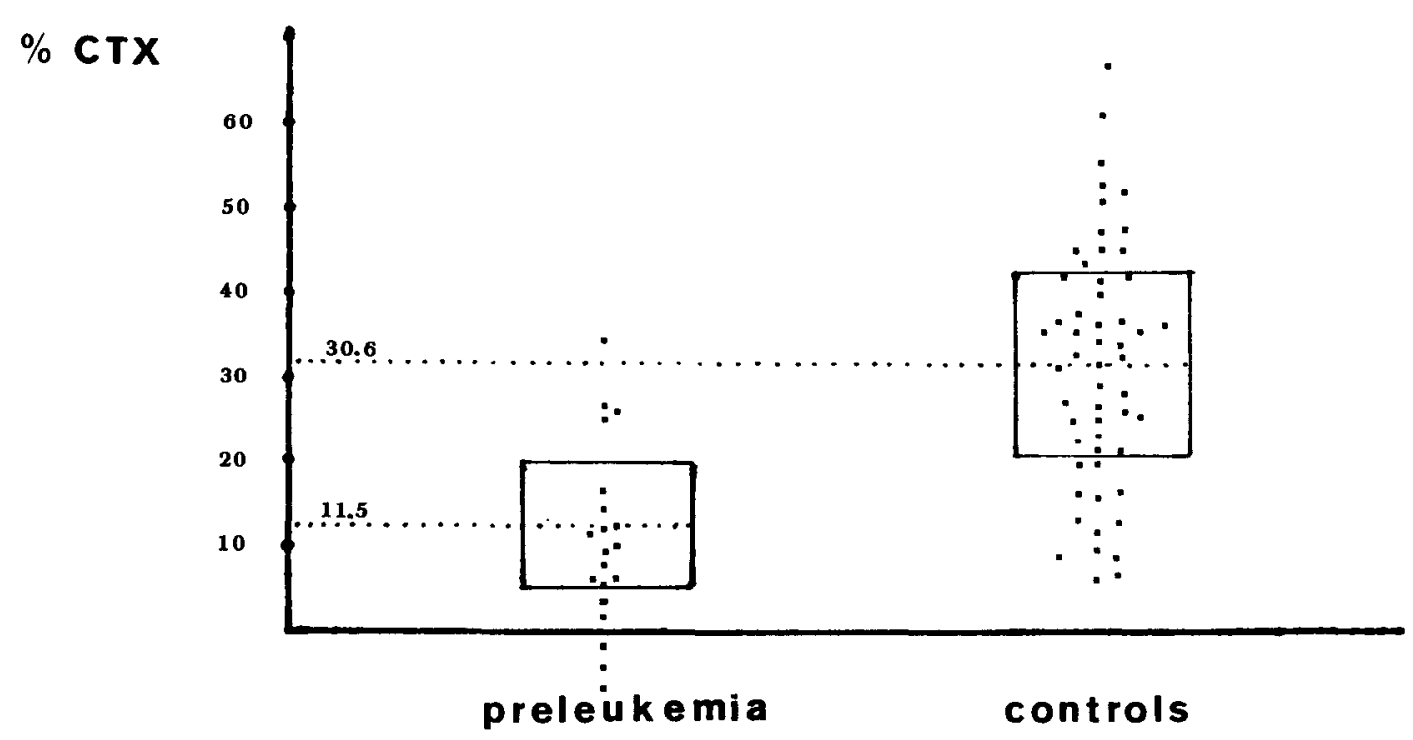

Fig. 1. NK activity in preleukemic patients compared with healthy controls. Mean \pm SD is indicated for each group 
Table 2. Percentage of NK activity in 20 patients according to preleukemic syndrome

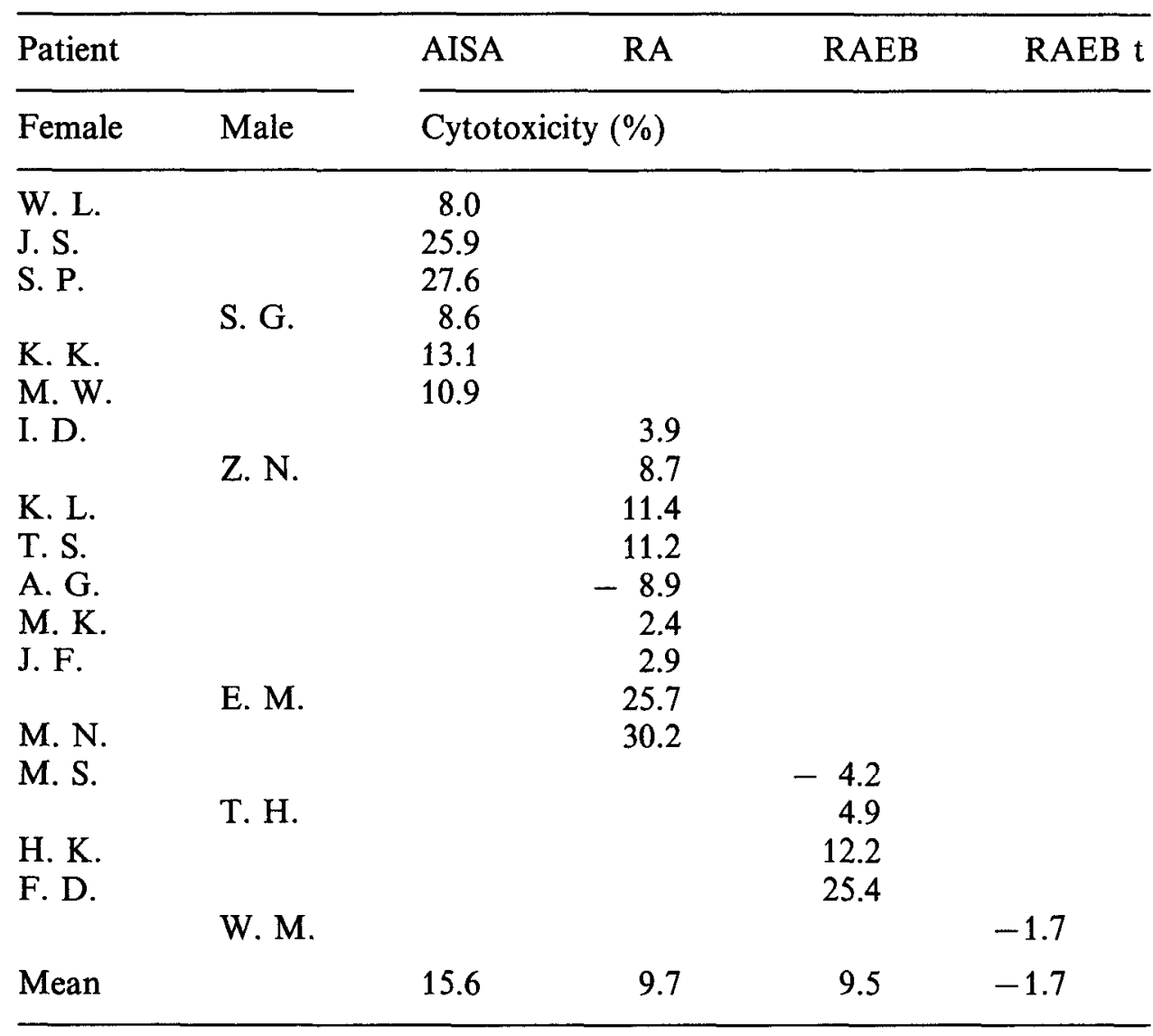

These preliminary observations show that very low NK activity might be connected with a high risk for overt leukemia. Furthermore, the preleukemic patients were divided into two groups on the basis of their risk for leukemic transformation. The "high-risk" group, consisting of patients with RA, RAEB, and RAEBt, showed a mean NK activity of $5.8 \%$. The "low-risk" group, consisting of patients diagnosed as having AISA, which has a better prognosis for long survival, showed a higher mean percentage of NK activity (15.6\%), but the difference was not statistically significant (Table 2 ).

\section{References}

1. Babcock GF, Phillips JH (1983) Human NK cells: light- and electron-microscopic characteristics. Surv Immunol Res 2:88-101

2. Benett JR, Catovsky D, Daniel MT, Flandrin G, Galton DAG, Gralnick HR, Sultan C (1982) Proposals for the classification of the myelodysplastic syndromes. Br J Haematol 51:189-199
3. Einhorn S, Blomgren H, Strander H (1978) Interferon and spontaneous cytotoxicity in man. I. Enhancement of the spontaneous cytotoxicity of peripheral lymphocytes by human leukocyte interferon. Int $\mathrm{J}$ Cancer 22:405-412

4. Hanna N (1985) The role of natural killer cells in the control of tumor growth and metastasis. Biochim Biophys Acta 780:213-226

5. Kaplan J, Callewaert DM (1978) Expression of human T-lymphocyte antigens by natural killer cells. J Natl Cancer Inst 60:961-964

6. Katz P, Zaytoun AM, Lee JH, Fauci AS (1984) In vivo Epstein-Barr virus - induced augmentation of natural killer cell activity in the Chédiak-Higashi syndrome. J Immunol 132:571-573

7. Lozzio CB, Lozzio BB (1975) Human chronic myelogenous cell line with positive Philadelphia chromosome. Blood 45:321-334

8. Ortaldo JR, Mantovani A, Hobbs D (1983) Effects of several species of human leukocyte interferon on cytotoxic activity of NK cells and monocytes. Int J Cancer 31:285-289

9. Ortaldo JR, Sharrow SD, Timonen T, Herberman RB (1981) Determination of surface antigens on highly purified human NK cells by flow cytometry with monoclonal antibodies. J Immunol 127:2401-2409 
10. Perussia B, Trinchieri G, Jackson A, Warner NL, Faust J, Rumpold H, Kraft D, Lanier LL (1984) The Fc receptor for IgG on human natural killer cells: phenotypic, functional, and comparative studies with monoclonal antibodies. J Immunol 133:180-189

11. Potter MR, Moore M (1979) Natural cytotoxic reactivity of human lymphocyte subpopulation. Immunology 37:187-194

12. Porzsolt $F$, Heimpel $H$ (1982) Impaired $T$-cell and NK-cell function in patients with preleukaemia. Blut 45:243-248

13. Roder JC, Haliotis T, Klein M (1980) A new immunodeficiency disorder in humans involving NK cells. Nature 284:553-555

14. Roder JC, Pross HF (1982) The biology of the human natural killer cell. J Clin Immunol 2:249-263

15. Rosenberg EB, Herberman RB, Levine PH (1972) Lymphocyte cytotoxicity reactions to leukaemia associated antigens in identical twins. Int J Cancer 9:648-658

16. Rosenberg EB, Mc Coy JL, Green SS (1974) Destruction of human lymphoid tissue-culture cell lines by human peripheral lymphocytes in ${ }^{51} \mathrm{Cr}$ release cytotoxicity assays. $\mathrm{J}$ Natl Cancer Inst 52:345-352

17. Santoli O, Trinchieri G, Morelta L (1978) Spontaneus cell-mediated cytotoxicity in hu- mans. Distribution and characterisation of the effector cell. Clin Exp Immunol 33:309318

18. Shaw ARE, Bleackley RC, Merryweather JP, Barr PJ (1985) Modulation of human natural killer cell activity by recombinant human interleukin 2. Cell Immunol 90:547-554

19. Takagi S, Kitagawa S, Takeda A, Minato N, Takaku F, Miura Y (1984) Natural killer - interferon system in patients with preleukaemic states. Br J Haematol 58:71-81

20. Takasugi M, Mickey MR, Terasaki $P$ (1978) Reactivity of lymphocytes from normal persons on cultured tumor cells. Cancer Res 33:2898-2902

21. Timonen T, Saksela E, Ranki A, Häyry $P$ (1979) Fractionation, morphological and functional characterisation of effector cells responsible for human natural killer activity against cell-line targets. Cell Immunol 48:133-148

22. Trinchieri G, Matsumoto-Kobayashi $M$, Clark SC, Seehra J, London L, Perussia B (1984) Response of resting human peripheral blood natural killer cells to interleukin 2. J Exp Med 160:1147-1169

23. West WH, Cannon GB, Kay HD (1977) Natural cytotoxic reactivity of effector cells. J Immunol 118:355-361 